\title{
Using Computer-Based Timeline Media to Teach English Tenses
}

\author{
Susana Teopilus \\ susanateopilus@ukwms.ac.id \\ $\&$ \\ Hendra Tedjasuksmana \\ hendra@ukwms.ac.id \\ English Department \\ Faculty of Teacher Training and Education \\ Widya Mandala Catholic University Surabaya \\ Surabaya, Indonesia \\ $\&$ \\ Diana Lestariningsih \\ dlestariningsih@yahoo.com \\ Electric Engineering \\ Faculty of Engineering \\ Widya Mandala Catholic University Surabaya \\ Surabaya, Indonesia
}

\begin{abstract}
The difference between English and Indonesian in the aspect of verb forms poses a big problem to Indonesian learners in learning the English Tenses. Indonesian learners are often unaware of the English time concept which affects verb forms. To overcome the problem, in this three-year research, Teopilus et al. have developed computer-based timeline media to teach the English Tenses. To find out the effectiveness of the developed media, 251 students from 4 (four) different senior high schools were given the instructions of the English Tense(s) using the timeline media. These subjects were given a pretest prior to the instruction and a posttest after it. The pretest scores and the posttest scores were statistically compared using the t-test formula. To obtain the users' opinions on the developed media, a questionnaire was distributed to 7 (seven) English teachers. The results of the data analysis yield the following findings: (1) There is a significant increase from the average of the subjects' pre-test scores to their post-test scores, and (2) The results of the users' questionnaires also give positive responses to the developed timeline media. This implies that the computer-based timeline media developed in this research helps Indonesian learners comprehend the English Tenses better
\end{abstract}

Keywords: timeline media, English Tense, computer-based

\section{Introduction}

The difference between English and English, especially the English Tenses. Indonesian in the aspect of verb forms poses a English verbs have several forms: infinitive big problem to Indonesian learners in learning form, present participle, preterite, and past 
participle; in addition, the tense and mode used to express an activity determines which verb form is used. Indonesian language, however, does not recognize these verb changes.

The findings of the previous research entitled "Problems in Applying English Tenses Faced by the Students of the English Education Study Program as Shown by Their Thinking Aloud Protocols" indicate that many students of the English Education Study Program, having completed all the structure classes offered, still made mistakes in using English Tenses; one of the causes is their inability to understand the time concept of the English Tenses (Teopilus and Winarlim, 2008).

This three-year research entitled 'Developing Computer-Based Timeline Media to Teach English Tenses', therefore, aimed at finding a solution to the problems experienced by most Indonesian learners in learning and mastering English Tenses. To do so, Teopilus et al. in the first two years of the research, developed the computer-based timeline media to teach twelve English Tenses. The developed timeline media are equipped with pictures, animation and sound to visualize the abstract time concept of the English Tenses and to make it easy for the Indonesian learners to understand the functions of the English Tense(s) taught. The developed timeline media were then tried out in the English classes. The third year of the research was devoted to disseminating the media to a number of English teachers so that they could also use them in their classes. The present research report, therefore, discusses the results of the implementation of the developed timeline media, called 'Timeline
Media for English Tenses', to teach English tenses in some English classes at the senior high school level. The analyzed results prove the effectiveness of the media in helping Indonesian learners comprehend the English Tenses. This paper starts by briefly discussing the background of the research, and the underlying theories used to support it. Next, it describes what has been done during the three-year journey of the research. Then, it elaborates the findings of the implementation of the developed timeline media in several high schools, followed by the results of the questionnaires from the users, in this case some senior high school teachers of English.

\section{Timeline Media for English Tenses}

Many English grammar books give timeline graphs in their sections of English Tenses. Rees (2005) states that timelines are diagrams that illustrate the reference to time made by a given piece of language. They are used to show how a particular language item (often a verb in a particular tense and aspect) places particular events or situations in time and in relation to other events. In English language teaching, particularly in the teaching of English Tenses, a timeline is a diagram which describes the time reference showing how an event or happening is placed in the timeline in relation to another event or happening.

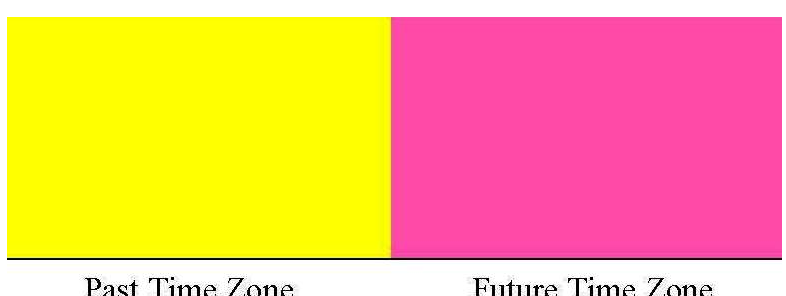

Present Time Zone

Fig. 1. Timeline Media 
In assigning the time zones in the timeline media, the area on the left of the vertical line represents the past time, the vertical line refers to the present time, and the area on the right of the vertical line refers to the future time. The concept of time or tense in English is used to refer to past, present, or future. In each of the tense categories, there are subcategories called aspects, which refer to the duration of an event. In English, there are four aspects, namely Simple, Progressive, Perfect, and Perfect Progressive. The Simple aspect does not show the beginning or the ending of an event, but it only shows whether an event happens or not. The Perfect aspect shows that the ending of the event is known and is used to emphasize that the event is over. The Progressive aspect indicates that an event is in progress. The Perfect Progressive aspect shows that an event has/had been and is/was in progress at a certain time.

The timeline media developed in this research consists of 14 modules and are equipped with animation and sound. The use of the timeline media gives the following benefits in helping Indonesian learners to comprehend the English Tenses: (1) Timeline media simplifies the abstract explanation about the past time, present time and future tense, and (2) Timeline media clearly visualizes the three time zones: past, present, and future; Indonesian learners will, therefore, immediately see which time zone is referred to in the action expressed in the sentence and what English Tense is correctly used to do so (Teopilus et al, 2014).

\section{Teaching English Tenses to Learners}

There are two approaches to teaching English grammar: deductive and inductive approaches. Nunan (2005) states that there are two basic ways to introduce a new grammar item, deductively and inductively. In a deductive approach, the teacher presents the grammar rules and then gives students exercises in which they apply the rule. In an inductive approach, the teacher presents samples of language, and the students have to come to an intuitive understanding of the rule. In relation to the teaching of English Tenses, when the deductive approach is used, a teacher will start with the explanation of the verb forms or usage and functions or uses, and after that he or she will give the students more examples and exercises so that they can use the tense correctly. The inductive approach is used when the teacher starts with examples of the verb forms to be taught, and students are guided to discover their conclusion of the verb forms. More examples and exercises are given to them so that they can use the verb forms correctly.

In teaching English tenses, teachers can adopt either the deductive or inductive approach, depending on the complexity of the time concepts and functions of the tense. For the simpler concepts, the inductive approach can be used; for the more complex ones, the deductive approach is recommended. The timeline media developed can be integrated in both of these approaches. Once the concepts have been understood by the learners, the teachers should give them meaningful exercises that will encourage them to apply the newly-obtained knowledge into practice so that it stays in their long term memory. The key to the successful teaching of the English Tenses is implanting the concept and providing the opportunity for the learners to frequently use them meaningfully in context so that they can use it correctly. For this 
purpose, learners need to do a lot of exercises. To this point, Nunan (2005) argues that research has shown that a grammatical item will be more successfully mastered by one's practicing 15 minutes over four days than by an hour's practice on a single day. This does indicate that repeating or revisiting a grammatical item several times will result in a better mastery.

\section{Learning Styles}

Conner (2007) argues that Learning styles classify different ways people learn and how they approach information. Nunan (2015) states that a learning style is the natural, habitual way that we go about learning. Learning styles have been classified in various ways. Christison (2003, in Nunan, 2015) distinguishes between cognitive styles, sensory styles, and personality styles. With reference to the different learning styles based on their sensory styles, students can be classified into 3 types: visual learning style, auditory learning style, and kinesthetic learning style. Visual style is learning by seeing. Students with this learning style benefit greatly from teaching that utilizes illustrations, charts, diagrams, videos, etc. Auditory learning style is learning by hearing. Students with this learning style benefits the lecture or oral explanation delivered in the classroom environment, as they are able to comprehend, process and retain the information provided. Kinesthetic style is learning by doing. Students with this style benefit from hands-on learning experience.

Students use a combination of all these three learning channels to receive and process information; one or more of these three styles is, however, more dominantly preferred and used in learning a new task. This dominant learning style is the best way for the respective students.

In order that the teaching of English Tenses can work effectively, it should accommodate the students' different learning styles. The computerized timeline media designed and developed in this research have the visual, auditory, and kinesthetic features. The visual feature is seen from the writing, pictures and animation used; the auditory feature is obtained from the voice and background music in the media; and the kinesthetic feature is also embedded in the animation used and the use of the navigation buttons when doing the independent study with the CD ROM. The computerized timeline media designed here are, therefore, expected to be able to accommodate all these different learning styles.

\section{Multimodal Texts in Teaching Tenses}

The present learners in senior high schools belong to generation $\mathrm{Z}$, who grows up with highly sophisticated social media and computer technology. Wikipedia states that this generation is generally defined with birth years ranging from the mid or late 1990s through the 2010 s or starting from the early 2000s. Generation Z learners are now living in an era where multimodal texts combine words, sounds, images, and movement. This implies that generation $\mathrm{Z}$ learners are used to getting exposed to multimodal texts too. The digital era has brought massive changes to their life styles, and they become less interested in text-based materials having no visuals and sounds. 
In English language teaching and learning, this type of learners will be more motivated and interested to learn the language when they are given explanations with multimodal texts which combine words, sounds, images, and movement. Walker and White (2013) state that learning is multimodal, and one of the special things with computer technology is it allows learners and teachers to combine modes such as sound, text and image in the classroom instruction.

Technology plays roles in education; it can be a learning resource, delivery system and productivity. Students can use computer programs, for example, to scaffold themselves with their needs, to acquire knowledge, and to create learning experience (Lee, Waxman, Wu, Michko, and Lin, 2013). With such programs they can find kinds of learning resources to improve their capacity, and they can experience with kinds of materials that they enjoy learning. What is more is they can use the programs for self-study. Thus, technology can be used as student-centered learning.

Technological resources can also be used outside the classroom; that is why students should be encouraged by the teachers to language concepts that they have difficulty to actively use technological resources in their self-directed learning. When doing this, students engage themselves to develop their capacity effectively (Lai, 2015). Technology that is used in class is supposed to provide to process as in comprehending the time zone in learning the English tenses. Mannan (2005) states that visual aids help the teacher accurately present the abstract concepts real and meaningful. Therefore, students will students with ease the understanding of easily understand the concepts more concrete so that learning is effective, meaningful and inspirational. Audio visuals can make the learners easy to understand concepts, specifically in this study the grammatical concepts, that is the concepts of the English tenses. Audio visual media enhance students' comprehension and learning; they enable students to holistically understand what words cannot convey. Audio visuals provide students with tools to make thought and organization processes visible. Complex concepts can be made simple and meaningful. Audio visuals assist students synthetically and analytically process and restructure ideas and information.

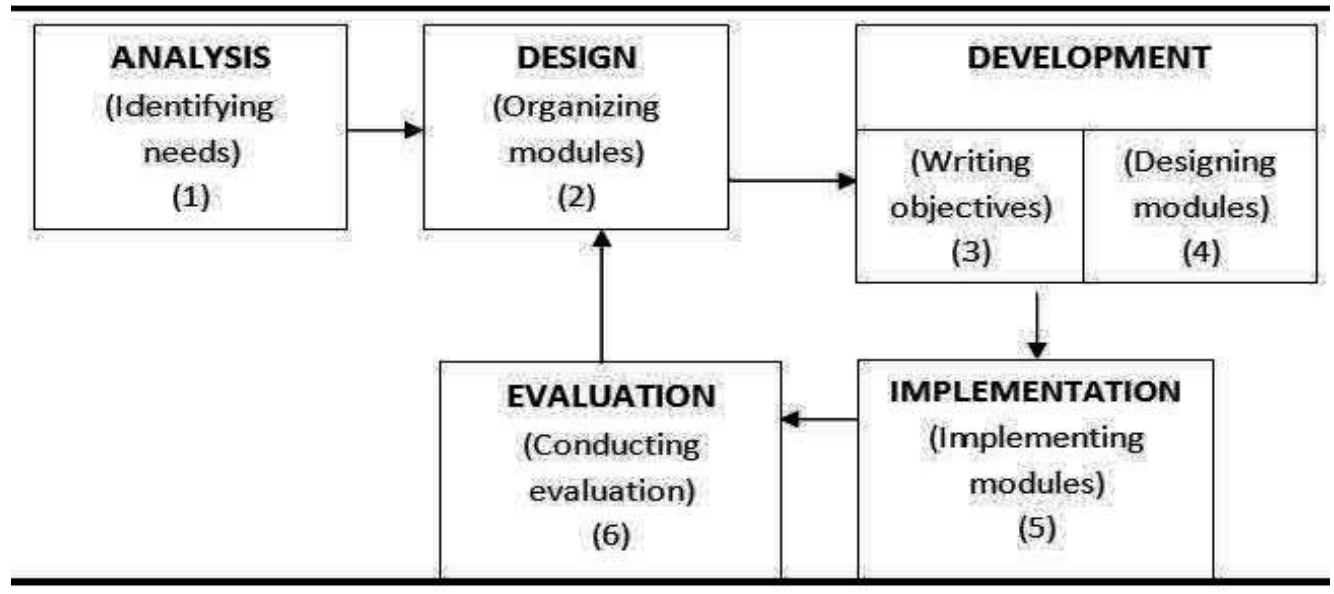

Fig. 2 Modified Addie Model of Instructional Desin 
The use of audio-visual aids in the teaching and learning processes has been researched by many scholars; most of the research results indicate benefits of such uses for learners. These research results have confirmed educators that learners will learn better in the classroom where teachers use teaching aids, which accommodate two or more sensory channels. Mayer (2011), in his research on multimedia instruction hypothesis, explored the question of whether adding visualizations to words in instruction messages can improve student learning, and his research finding points to the potential value of adding visualization to verbalinstruction. Finally, Boneva and Mihova (2012) believe learning that is experienced through two or more senses is much more likely to be retained by students. In teaching English tenses, teachers are, therefore, encouraged to make use of multisensory channels that can stimulate multimodal learning.

\section{A Three-Year Journey Development}

Basing on the findings of the previous research (Teopilus \& Winarlim, 2008), which served as the needs analysis to justify the research objective, Teopilus et al developed the computer-based timeline media to teach English Tenses to Indonesian learners. The ADDIE Model of instructional development is adopted and adapted in developing the instructional modules of the computer-based timeline media to teach English Tenses in this research. The following diagram illustrates the design sequence of the present module development.

The first four steps (steps 1-4) are related to the developing of the modules; step 5 is related to the implementation of the modules; and step 6 is related to the evaluation of the effectiveness of the modules after they are implemented. Steps 1-4 are conducted in the first and second years of the research. Steps 56 , which are related to the implementation of the computer-based timeline media developed for teaching English Tenses in the classrooms and the evaluation of the effectiveness of the media, are conducted in the third year of the research.

In the first year of the research (2014), Teopilus et al develop the modules of teaching the first English Tenses using computer-based timeline media, covering Simple Present Tense, Present Progressive Tense, Simple Past Tense, Past Progressive Tense, Simple Future Tense, and Future Progressive Tense. These six modules are preceded with a module of Introduction to Time Concept in English Tenses. There are, therefore 7 modules altogether that have been developed and tried-out and tested in the first year of research. The result of the try-out indicates that these modules are proved to be able to increase the subjects' knowledge of the related English Tenses significantly.

In the second year (2015), six more modules of teaching the next six English Tenses (namely Present Perfect Tense, Perfect Progressive Tense, Past Perfect Tense, Past Perfect Progressive Tense, Future Perfect Tense, and Future Perfect Progressive Tense) are developed. The module of Overall Review of English Tenses is developed to summarize the previous twelve modules. On the whole, there are 7 modules that have been developed in the second year. These modules are also tried out and tested, and the findings also show that they significantly enhance the subjects' knowledge of the English Tenses.

In the third year (2016), all the fourteen modules are refined and compiled together 
into one DVD entitled 'Timeline Media for English Tenses'. Next, it is disseminated to 18 English teachers of 10 senior high schools in Surabaya and 26 English teachers of 10 senior high schools in Mojokerto. Following the dissemination, class observations of eight teachers using these media in teaching English Tense(s) to their students are conducted. There are 6 classes in 2 schools in Surabaya and 2 classes in 2 schools in Mojokerto which have been observed. The remaining section of this paper discusses the results of the implementation of the developed timeline media done by these English teachers

\section{Research Method}

\section{Participants}

To find out the effectiveness of the developed timeline media, this research, a pretest- posttest design, used 251 senior high school students (grade X to grade XII) as the research subjects. These subjects were from 4 different senior high schools, two of which were located in Surabaya, a big city in East Java and the other two were located in Mojokerto, a small city in East Java. These four schools were randomly chosen from 20 (twenty) schools which had sent their teachers to join the research dissemination of the use of the computer-based timeline media to teach English Tenses. These schools used the national curriculum in the teaching and learning processes, and the medium of instruction was Indonesian. As all of the subjects were in the senior high school levels, they had got English lessons in the classrooms for at least 10 years. In fact, they had been taught most of the afore-mentioned twelve English Tenses before receiving the instruction of the English tense using the developed timeline media in this research.

In addition to finding out the effectiveness of the developed timeline media, the research also aimed at obtaining opinions from the English teachers who used the media in teaching the English Tense(s) to their students in their classes. To do so, the developed questionnaire was distributed to 8 (eight) users, who were English teachers in high schools, and 7 (seven) of whom returned the completed questionnaire.

\section{Research Instruments}

There are 2 instruments used in this research: (1) A test on English Tenses, and (2) a questionnaire.

The English Tense(s). The test, serving as the pretest and post test, is to measure the subjects' knowledge of the English Tense(s) taught. As the implementation was done in senior high schools, it was the school English teachers who did the teaching using the developed media.

It is a common practice for school teachers to give a pretest prior to his/her instruction, and a posttest after his/her instruction. The respective teacher is assumed to know what learning outcome(s) to be achieved in his or her lesson and what level of achievement to be included in the test for his/her students based on the English syllabi of the National Curriculum. In this research, therefore, the test given to the subjects of a certain class was made by the respective English teacher who taught the class.

The questionnaire. This was used to find out the opinions of the English teachers, or the users of the timeline media developed. The questionnaire consisted of six questions asking about the users' opinions on (a) the benefit of the 'Timeline Media for English 
Tenses' to help the students to comprehend the time concept in English Tenses, (b) the layout of the pictures and the animation in the timeline media to help the students to comprehend the time concept of the English Tense taught, (c) the clearness of the native speaker's voice in the media to help the students understand the time concept of the English Tense taught, (d) the students' interest to learn English Tenses using the computer-based timeline media developed, (e) the ease of using the developed timeline media, and (f) the role of the developed computer-based timeline media in enhancing the students' understanding the English Tense(s) taught.

\section{Procedure}

The participants were in their intact classes (referred to as Class A to Class H).
Each of the English sessions lasted for 90 minutes, and the time was allocated as follows:

- Pretest: 20 minutes

- Instruction: 50 minutes

- Posttest: 20 minutes

Prior to receiving their teacher's instruction of English Tense(s) using the developed timeline media, the subjects of each class were given a pretest to do. The pretest was related to the English Tense(s) to be taught by the respective teacher. After the instruction, they were given a post test to do. Then the scores of the pretest were statistically compared to the scores of the posttest using the t-test formula to find out whether there was any significant difference between them or not.

Table 1

\section{Results}

Results of T-test Calculation

\begin{tabular}{|c|c|c|c|c|c|c|c|c|c|}
\hline \multirow{2}{*}{ No } & \multirow{2}{*}{ School } & \multirow{2}{*}{$\begin{array}{l}\text { Group/ } \\
\text { Grade }\end{array}$} & \multirow{2}{*}{ Tense(s) Taught } & \multirow{2}{*}{$\begin{array}{c}\text { No } \\
\text { of Ss }\end{array}$} & \multicolumn{2}{|c|}{ Mean } & \multirow{2}{*}{$t_{\text {table }}$} & \multirow{2}{*}{ tcal } & \multirow{2}{*}{ Result } \\
\hline & & & & & Pre & Post & & & \\
\hline 1 & Sby 1 & $\begin{array}{l}\text { AlX } \\
\text { Science } \\
\text { Program }\end{array}$ & $\begin{array}{l}\text { Simple Past Tense \& Past } \\
\text { Progressive Tense }\end{array}$ & 35 & 36.17143 & 64.91429 & 2.03224 & 9.15543 & $t_{\text {cal }}>t_{\text {table }}$ \\
\hline 2 & Sby 1 & $\begin{array}{l}\mathrm{B} / \mathrm{X} \\
\text { Science } \\
\text { Program }\end{array}$ & $\begin{array}{l}\text { Simple Past Tense \& Past } \\
\text { Progressive Tense }\end{array}$ & 28 & 53.35715 & 78.46429 & 2.05183 & 9,15543 & $\mathrm{t}_{\text {cal }}>\mathrm{t}_{\text {table }}$ \\
\hline 3 & Sby 1 & $\begin{array}{l}\mathrm{C} / \mathrm{X} \\
\text { Science } \\
\text { Program }\end{array}$ & $\begin{array}{l}\text { Simple Past \& Past } \\
\text { Progressive Tense }\end{array}$ & 37 & 61.594595 & 71.94595 & 2.02809 & 6.21549 & $\mathrm{t}_{\text {cal }}>\mathrm{t}_{\text {table }}$ \\
\hline 4 & Sby 1 & $\begin{array}{l}\mathrm{D} / \mathrm{X} \\
\text { Social } \\
\text { Program }\end{array}$ & $\begin{array}{l}\text { Simple Past Tense \& Past } \\
\text { Progressive Tense }\end{array}$ & 37 & 39.621622 & 58.32432 & 2.02809 & 6.09700 & $t_{\text {cal }}>t_{\text {table }}$ \\
\hline 5 & Sby 2 & $\begin{array}{l}\text { E/XI } \\
\text { Science } \\
\text { Program }\end{array}$ & Simple Past Tense & 35 & 72.00000 & 83.85714 & 2.03224 & 4.55770 & $t_{\text {cal }}>$ table \\
\hline 6 & Sby 2 & $\begin{array}{l}\text { F/XII } \\
\text { Science } \\
\text { Program }\end{array}$ & $\begin{array}{l}\text { Future Perfect Tense \& } \\
\text { Future Perfect Progressive } \\
\text { Tense }\end{array}$ & 34 & 47.79412 & 94.26471 & 2.03452 & 11.22600 & $\mathrm{t}_{\text {cal }}>\mathrm{t}_{\text {table }}$ \\
\hline 7 & Mjk 1 & $\begin{array}{l}\text { G/XI } \\
\text { Science } \\
\text { Program }\end{array}$ & $\begin{array}{l}\text { Present Perfect Tense \& } \\
\text { Present Perfect Progressive } \\
\text { Tense }\end{array}$ & 23 & 32.95652 & 53.56522 & 2.07387 & 6.73950 & $\mathrm{t}_{\text {cal }}>\mathrm{t}_{\text {table }}$ \\
\hline 8 & Mjk 2 & $\begin{array}{l}\mathrm{H} / \mathrm{XII} \\
\text { Social } \\
\text { Program }\end{array}$ & $\begin{array}{l}\text { Simple Present Tense \& } \\
\text { Present Progressive Tense }\end{array}$ & 22 & 15.09091 & 23.90909 & 2.07961 & 3.65225 & $\mathrm{t}_{\text {cal }}>\mathrm{t}_{\text {table }}$ \\
\hline
\end{tabular}


The results of the t-test calculation (of the subjects' pretest and posttest scores) of all the eight classes are presented in the above Table 1. While the results of the t-test calculation of all the classes indicate that there is a significant difference between the subjects' pretest scores and their posttest scores. This

Table 2

Results of Questionnaire Analysis proves that the timeline media developed in this research, to some extent, have effectively increased the learners' knowledge of the English tenses taught. The results of the questionnaire analysis are presented in the table below.

\begin{tabular}{|c|c|c|c|c|c|}
\hline \multirow{2}{*}{\multicolumn{2}{|c|}{ No Questions }} & \multicolumn{4}{|c|}{ Response } \\
\hline & & Very Good & Good & Bad & Very Bad \\
\hline 1 & Q 1: benefit of the media & 3 & 4 & & \\
\hline 2 & Q 2: layout of the media & 5 & 2 & & \\
\hline 3 & Q 3: clearness of the media features & 5 & 2 & & \\
\hline 4 & Q 4: students' interest in the media & 2 & 5 & & \\
\hline 5 & Q 5: ease of using the media & 4 & 3 & & \\
\hline 6 & Q 6: role of the media & 4 & 3 & & \\
\hline
\end{tabular}

The results of the questionnaire analysis indicate the positive responses of these teachers after using the media in their classes. They gave very good responses (43\%) and good responses $(57 \%)$ to the questions asking about the benefit, very good responses (71\%) and good responses (29\%) to the layout of the pictures and animation, very good responses (71\%) and good responses (29\%) to native speaker's voice, very good responses (29\%) and good responses (71\%) to students' interest, very good responses (57\%) and good responses $(43 \%)$ to the ease of operating the media, and very good responses (57\%) and good responses $(43 \%)$ to the role of the media to enhance their students' understanding of the English Tense(s) taught.

\section{Discussion}

In general, the developed timeline media can enhance the learners' understanding of the English Tenses. This has been proved by the increase in the their posttest scores, which shows a significant gain score obtained after they have been given the instruction using the computer-based timeline media developed. In the classroom instruction, the developed timeline media can simplify the abstract explanation about the time concept; furthermore, the timeline media, along with the voice, pictures, and animation, help to clearly visualize the activities or happenings illustrated in the three time zones. The learners can, therefore, immediately see which time zone is referred to in the action expressed in the sentence and what English Tense is used to express it correctly.

With this timeline media, learners are made accustomed to 'seeing' actions or events depicted in the related time zone. Gradually, they are brought to the 
understanding that actions or events happening in the past time zone are to be expressed using the Past Tenses, such as Simple Past Tense, Past Progressive Tense, Past Perfect Tense, or Past Perfect Progressive Tense. When events or actions take place in the present time zone, meaning that they are related to the present time, these events are to be expressed using the Present Tenses, such as Simple Present Tense, Present Progressive Tense, Present Perfect Tense, or Present Perfect Progressive Tense. Finally, when events or actions occur in the future time zone, these events or actions need to be expressed using the Future Tenses, such as Simple Future Tense, Future Progressive Tense, Future Perfect Tense, or Future Perfect Progressive Tense. When learners are aware of the importance of understanding the time concept in English Tenses, they will be able to use the correct verb forms to express actions or events based on the time zones where they happen. Thus, they will not use an English Past Tense to express a present happening or vice versa.

Besides, the addition of sound in the developed media, the native speaker's voice and the background music, also helps the subjects retrieve the learned concept easily. Thus, the pictures and animation in the media accompanied with the sound facilitate the retaining process of the learned knowledge in the subjects' long-term memory, making it possible for them to remember it when they need to use it. This is just in line with Boneva \& Mihova (2012) who argue that learning which is experienced through two or more senses is much more likely to be retained by students.
In this study, though there is improvement in the subjects' knowledge of the English Tenses taught, many of their post test scores are still considered insufficient. This happens because they were not given any time to do any related exercises. Their post test scores would have been much higher if they had done some related exercises. Once the time concept of the English tense(s) is understood, learners should be given meaningful exercises related to the tenses taught to retain the knowledge in their longterm memory. After all, the key to the successful teaching of the English Tenses is implanting the time concept and providing the opportunity for the learners to frequently use them meaningfully in context as what Nunan (2005) argues that a grammatical item will be more successfully mastered by one's practicing 15 minutes over four days than by an hour's practice on a single day. Repeating or revisiting a grammatical item several times will result in a better mastery.

These research findings prove that the subjects' knowledge of the English Tenses improves after they have been given instruction of the English tense using the developed timeline media. With these findings, it can be concluded that the use of the computer-based timeline media developed in this research (Timeline Media for English Tenses) will be able to help Indonesian learners comprehend the twelve English Tenses more effectively.

The series of the research activities conducted in three years have yielded the following conclusions:

- The teaching of English, in this case English Tenses, needs to be supported with teaching media that can accommodate students' needs, interest, and learning styles. 
In the digital era, the use of computer technology, such as the developed computerbased timeline media, is recommended as it fulfills their needs, interest, and learning styles.

- Indonesian learners need to be guided in understanding the time concept (with the three time zones: past, present, and future), which is very crucial for English Tenses.

- The developed timeline media show the time zones. The media, equipped with the animation and voice, can visualize the time concept of the twelve English tenses; thus learners are helped to use the correct verb forms to express the events.

- The timeline media developed in this research can enhance the learners' understanding of the English Tenses presented. This is proved by the t-test calculation, which shows a significant increase from the pretest scores to the posttest scores.

(C) Susana Teopilus, Hendra Tedjasuksmana \& Diana Lestariningsih.

Susana Teopilus is a senior lecturer at the English Language Teaching Department, Faculty of Teacher Training and Education, Widya Mandala Catholic University Surabaya. She teaches English Language Teaching Methodology, Writing, and Teaching English to Young Learners. She has conducted research related to the courses taught and the classroom language of in-service teacher development.

Hendra Tedjasuksmana is a senior lecturer at the English Language Teaching Department as well as at the Master's Program in ELT, Widya Mandala Catholic University Surabaya. He teaches Applied Linguistics, Syntax, Discoursesis and English skills. His research interests include language acquisition and use, and discourse.

Diana Lestariningsih is a full-time lecturer at the Electrical Engineering Department, Faculty of Engineering, Widya Mandala Catholic University Surabaya. She teaches Electronic Circuit, Analog Electronic, Anatomy and Phisiology for Biomedical Engineering, Computer Application for Biomedical Engineering.She has conducted research related to the courses taught and aid tools for blind \& deaf people.

\section{References}

Boneva, Boneva, D., \& Mihova, E. (2012). Dyslang Module 8 - Learning Styles and Learning Preferences. (J. Fernando, \& D. McCarney, Eds.) Bulgaria. Retrieved from http://dyscovery.research.southwales.ac.uk/m edia/files/documents/2014-0116/Module_8.pdf

Corner, M. (n.d.). "Introduction to Learning Styles." Ageless Learner, 1997-2007. Retrieved from http://agelesslearner.com/ intros/lstyleintro.html

Ellis, R. (March 2006). Current Issues in the Teaching of Grammar : An SLA Perspective. TESOL Quarterly Vol. 40 No. 1.
Lai, C. (2015). Modeling teachers' influence on learners' self-directed use of technology for language learning outside the classroom. Computers \& Education 82, 74-83.

Learning Styles Or, How We Go From the Unknown To the Known. (n.d.). Retrieved from Kilde: http//www.nwlink.com/ donclark/hrd/learnin $\mathrm{g} /$ styles.html

Learning Styles-Visual, Auditory and Kinesthetic. (2014, November 14). Retrieved from hhtp://www.personalitymax.com/learningstyles

Lee, Y.H., Waxman. H., Wu, J.Y., Michko, G., \& Lin, G. (2013). Revisit the effect of teaching 
and learning with technology. Educational Technology \& Society 16 (1), 133-146.

Mannan, A. (2005). Modern education: Audiovisual aids. New Delhi: Anmol Publications.

Mayer, R. E. (2011). Instruction Based on Visualizations. In R. E. Mayer, \& P. A. Alexander, Handbook of Research on Learning and Instruction (pp. 427-445). New York: Routledge.

Molenda, M. (2003, May/June). In Search of the Elusive ADDIE Model. Retrieved November 15, 2014, from Performance Improvement: www.comp.dit.ie/dgordon/courses/ilt/ilt0004/i nsearchofelusiveaddie.pdf

Nunan, D. (2005). Practical English Language Teaching: Grammar. Singapore: McGrawHill ESL/ELT, McGraw-Hill Companies, Inc.

Nunan, D. (2015). Teaching English to Speakers of Other Languages: an Introduction. New York: Routledge.

Rees, G. (2005, April 19). Timelines. British Council BBC.

Salaberry, M. (2001). The use of technology for second language learning and teaching: A retrospective. The Modern Language Journal, Vol. 85, No. 1, 39-56.

Tedjasuksmana, H.; Teopilus, S. (2016). The Progressive Aspects in the Grammatical Comptence of First Semester Students of the English Department. 5th ELTLT International Conference 2016. Semarang: State University of Semarang.
Teopilus, S.; Winarlim, H.S. \& Antonia, D.L . (2014). Developing Computer-Based Timeline Media to Teach Egnlish Tenses . The 8th DEPISA International Conference 2014. Jakarta: State University of Jakarta.

Teopilus, S.; Tedjasuksmana, H. (2016). The Indonesian Learners' Grammatical Competence of English Perfect Tenses. Conference Proceedings. The 63rd TEFLIN International Conference 2016. Surabaya: University of PGRI Adi Buana Surabaya. .

Teopilus, S.; Tedjasuksmana, H., \& Antonia, D.L. (2015). The Effect of Using Computer-Based Timeline Media on Learners' Mastery of English Tenses: A Preliminary Study. The 4th ELTLT International Conference 2015. Semarang: State University of Semarang.

Teopilus, S.; Winarlim, H. S. (2008). Problems in Applying English Tenses Faced by the Students of the English Education Study Program as Shown by Their Thinking Aloud Protocols. Surabaya: FKIP Widya Mandala Catholic University Surabaya I-MHERE Research Grant.

Walker, Aisha; White, Goodith. (2013). Technology Enhanced Language Learning: connecting theory and practice. Oxford: Oxford University Press.

Wikipedia . (2016, April 06). Retrieved from the free encyclopedia: https://en. wikipedia.org/ wiki/Generation_Z 